\title{
More than meets the Kappa for Antibody Superantigen Protein L $(\mathbf{P p L})$
}

1 Wei-Li Ling ${ }^{1,2}$, Joshua Yi Yeo', Yuen-Ling Ng ${ }^{2}$, Anil Wipat ${ }^{3}$, Samuel Ken-En Gan*1,4

${ }^{1}$ Antibody \& Product Development Lab, Experimental Drug Development Centre - Bioinformatics Institute, Agency for Science, Technology and Research (A*STAR), Singapore, Singapore

${ }^{2}$ Newcastle Research and Innovation Institute (NewRIIS), Singapore, Singapore

$7 \quad{ }^{3}$ School of Computing, Newcastle University, Newcastle upon Tyne, UK

$8 \quad{ }^{4}$ James Cook University, Singapore, Singapore

* Correspondence:

11 Samuel Ken-En Gan

12 samgan@apdskeg.com; samuel_gan@eddc.a-star.edu.sg

Keywords: Pertuzumab, Trastuzumab, IgG1, VH families, VK families, Protein L, Protein A, Protein G, Immunoglobulin Superantigen.

\section{Abstract}

Immunoglobulin superantigens play an important role in the affinity purification of antibodies and underlie the microbiota-immune axis at mucosal areas Focussing on the Staphylococcal Protein A (SpA), Streptococcal Protein G (SpG), and the Finegoldia Protein L (PpL) that were previously thought to bind to only specific regions of human antibodies, a systematic and holistic analysis of the antibody regions using 63 antibody permutations involving six $\mathrm{V} \kappa$ and seven $\mathrm{VH}$ region $\mathrm{IgG} 1$ revealed showed novel PpL-antibody interactions. While $\mathrm{SpA}$ and $\mathrm{SpG}$ showed relatively consistent interactions with the antibodies, our findings showed PpL binding to certain VH-Vк2, 5 and 6 interactions had contribution by other antibody regions. The findings of this have implications on PpL-based affinity antibody purifications and antibody design as well as provides novel insights to PpL-based microbiota-immune axis effects.

\section{Introduction}

B-cell superantigens bind antibodies or immunoglobulins (Ig) to hyperstimulate populations of 
mechanism to escape from the host immune system (Spaulding et al., 2013). Notably there are three widely-used antibody superantigens also known as immunoglobulin binding proteins (IBP): Protein $\mathrm{G}(\mathrm{SpG})$ which binds the heavy chain constant region of the IgG subtypes (IgG1-4) and is produced the by groups C and G of Streptococcal bacteria (Sjöbring et al., 1991); Protein A (SpA) produced by Staphylococcus aureus which also binds to the heavy chain constant region of IgG1, 2, and 4 and also the variable heavy (VH) 3 framework (VH3) (GROV et al., 1964;Sasso et al., 1991;Su et al., 2021); and Protein L (PpL) produced by Finegoldia magna (previously known as Peptostreptococcus magnus) which binds to the variable light kappa $\kappa$ (Vк) chain families 1,3,4 (Nilson et al., 1992) at the framework (FWR) 1 region with influence by the other regions (Su et al., 2017).

When bound to the antibodies, these superantigens can reduce the binding of the antibodies to their antigen (Ling et al., 2021), possibly reducing avidity through steric hindrances as in the case of IgM (Samsudin et al., 2020), cause unwanted activation (Su et al., 2021) with downstream effects depending on their isotype (discussed in (Ling et al., 2020a;Gan, 2021)).

With both IgG and Vк as the predominant isotypes in humans (Haraldsson et al., 1991;Janeway et al., 2001), superantigen proteins A, G, and L are likely to underlie significant microbiota-immune axis interactions especially at colonization of mucosal areas. Nonetheless, the problem extends to antibody purification process at which these superantigens are often used. Considering that most therapeutic antibodies are of the $\mathrm{IgG}$ and $\kappa$ isotypes, unwanted interactions of such superantigens produced by commensals at the natural colonization sites can influence the microbiota-immune axis.

Given the widespread implications of these three superantigens, a holistic (Phua et al., 2019; Ling et al., 2020a) and systematic antibody-superantigen investigation using 63 of our previously engineered antibodies (Ling et al., 2018;Lua et al., 2018;Ling et al., 2020b) was performed involving six $\mathrm{V} \kappa$ and seven $\mathrm{VH}$ IgGs finding novel interactions for PpL but not for $\mathrm{SpA}$ and SpG.

\section{Materials and Methods}

\subsection{Recombinant Antibody Production}

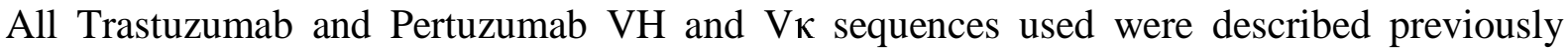
(Ling et al., 2018;Ling et al., 2020b). Briefly, the genes were sub-cloned into pTT5 vector (Youbio, Cat: VT2202) using restriction enzyme sites, as previously performed (Su et al., 2017;Ling et al., 2018; Lua et al., 2018; Lua et al., 2019a;Ling et al., 2020b). The plasmids were transformed into competent E. coli (DH5 $\alpha$ ) strains (Chan et al., 2013) followed by plasmid extraction (Biobasic Pte Ltd, Cat: BS614).

Transfection, production, and purification and were performed as described previously (Ling et al., 2018; Ling et al., 2020b).

\subsection{Binding Affinity Quantification}

Measurements of superantigen ka and kd using the OctetRed ${ }^{\circledR}$ were performed using PpL (Sartorius, Cat: 18-5185), SpA (Sartorius, Cat: 18-5012), and SpG (Sartorius, Cat: 18- 18-5083) 
bioRxiv preprint doi: https://doi.org/10.1101/2021.11.26.470168; this version posted November 27, 2021. The copyright holder for this preprint (which was not certified by peer review) is the author/funder, who has granted bioRxiv a license to display the preprint in perpetuity. It is made available under aCC-BY-NC-ND 4.0 International license.

Running Title

71 biosensor to Pertuzumab and Trastuzumab IgG1 variants in solution. The program and steps used

72 were as previously described (Su et al., 2017;Ling et al., 2018;Lua et al., 2018;Su et al., 2018;Lua et

73 al., 2019b;Ling et al., 2020b;Su et al., 2021).

$\begin{array}{lll}76 & 3 & \text { Results }\end{array}$

77

78

\subsection{Bio-Layer Interferometry (BLI) measurement of recombinant IgG1 variants to Protein A (SpA)}




\begin{tabular}{|c|c|c|c|c|c|c|c|}
\hline \multicolumn{4}{|c|}{ Pertuzumab variants binding Protein A } & \multicolumn{4}{|c|}{ Trastuzumab variants binding Protein $A$} \\
\hline $\begin{array}{l}\text { Variable } \\
\text { Pairings } \\
\end{array}$ & $\begin{array}{c}\text { KD } \\
\left(\mathbf{M}, 10^{-9}\right) \\
\end{array}$ & $\begin{array}{c}\text { ka } \\
\left(1 / \mathrm{Ms}, 10^{4}\right) \\
\end{array}$ & $\begin{array}{c}\text { kd } \\
\left(1 / \mathrm{s}, 10^{-4}\right) \\
\end{array}$ & $\begin{array}{l}\text { Variable } \\
\text { Pairings } \\
\end{array}$ & $\begin{array}{c}\text { KD } \\
\left(\mathbf{M}, 10^{-9}\right) \\
\end{array}$ & $\begin{array}{c}\text { ka } \\
\left(1 / \mathrm{Ms}, 10^{4}\right) \\
\end{array}$ & $\begin{array}{c}\text { kd } \\
\left(1 / \mathrm{s}, 10^{-4}\right) \\
\end{array}$ \\
\hline к1-H1 & 1.58 & 37.79 & 5.92 & к1-H1 & \multirow{4}{*}{\multicolumn{3}{|c|}{ Not Produced }} \\
\hline к1-H2 & 1.58 & 41.43 & 6.56 & к1-H2 & & & \\
\hline к1-H3 & 0.64 & 53.29 & 3.26 & к1-H3 & & & \\
\hline к1-H4 & 1.56 & 38.64 & 6.01 & к1-H4 & & & \\
\hline к1-H5 & \multirow{2}{*}{\multicolumn{3}{|c|}{ Not Produced }} & к1-H5 & 1.06 & 29.07 & 3.07 \\
\hline к1-H6 & & & & к1-H6 & \multicolumn{3}{|c|}{ Not Produced } \\
\hline к1-H7 & 1.17 & 42.74 & 5.02 & к1-H7 & 0.66 & 44.31 & 2.93 \\
\hline$\kappa 2-\mathrm{H1}$ & 1.90 & 33.08 & 6.32 & к2-H1 & 1.49 & 17.97 & 2.68 \\
\hline к2-Н2 & 1.82 & 35.57 & 6.47 & к2-H2 & 1.46 & 17.32 & 2.14 \\
\hline к2-H3 & 0.76 & 55.68 & 4.23 & к2-H3 & 0.24 & 45.66 & 1.08 \\
\hline к2-H4 & 1.57 & 36.21 & 5.68 & К2-H4 & 1.29 & 35.58 & 4.51 \\
\hline к2-H5 & 1.62 & 35.83 & 5.82 & К2-H5 & 1.11 & 60.04 & 6.64 \\
\hline к2-Н6 & 1.55 & 38.00 & 5.91 & к2-Н6 & 1.79 & 25.36 & 4.51 \\
\hline к2-H7 & 1.15 & 47.37 & 5.44 & к2-H7 & 0.53 & 57.16 & 3.04 \\
\hline$\kappa 3-\mathrm{H} 1$ & 1.06 & 37.25 & 3.92 & к3-Н1 & 0.25 & 45.00 & 1.08 \\
\hline к3-Н2 & 1.57 & 40.11 & 6.30 & к3-Н2 & 1.67 & 32.31 & 5.36 \\
\hline к3-Н3 & 0.69 & 58.94 & 4.07 & к3-Н3 & 1.12 & 20.69 & 2.31 \\
\hline к3-Н4 & 1.50 & 36.19 & 5.45 & к3-Н4 & 2.30 & 23.37 & 5.33 \\
\hline к3-H5 & 1.57 & 39.18 & 6.18 & к3-Н5 & 0.53 & 64.07 & 3.25 \\
\hline к3-Н6 & 1.43 & 42.28 & 6.04 & к3-Н6 & 0.25 & 45.00 & 1.08 \\
\hline к3-Н7 & 1.12 & 44.12 & 4.93 & к3-Н7 & 1.67 & 32.31 & 5.36 \\
\hline к4-Н1 & 1.70 & 37.79 & 6.43 & к4-H1 & 1.95 & 18.22 & 3.55 \\
\hline к4-Н2 & 1.46 & 39.39 & 5.77 & к4-Н2 & \multicolumn{3}{|c|}{ Not Produced } \\
\hline к4-H3 & 0.58 & 43.12 & 2.46 & к4-H3 & 0.25 & 45.00 & 1.08 \\
\hline$\kappa 4-\mathrm{H} 4$ & 1.61 & 36.02 & 5.73 & $\kappa 4-\mathrm{H} 4$ & 1.67 & 32.31 & 5.36 \\
\hline к4-H5 & 1.88 & 34.13 & 6.40 & к4-H5 & 1.12 & 20.69 & 2.31 \\
\hline к4-H6 & 1.85 & 31.10 & 5.76 & к4-H6 & 2.30 & 23.37 & 5.33 \\
\hline к4-H7 & 1.33 & 36.54 & 4.85 & к4-H7 & 0.53 & 64.07 & 3.25 \\
\hline$\kappa 5-\mathrm{H1}$ & \multirow{2}{*}{\multicolumn{3}{|c|}{ Not Produced }} & к5-Н1 & \multirow{2}{*}{\multicolumn{3}{|c|}{ Not Produced }} \\
\hline$\kappa 5-H 2$ & & & & $\kappa 5-\mathrm{H} 2$ & & & \\
\hline$\kappa 5-\mathrm{H3}$ & 0.94 & 18.65 & 1.74 & $\kappa 5-\mathrm{H3}$ & 0.72 & 24.60 & 1.74 \\
\hline к5-H4 & \multirow{3}{*}{\multicolumn{3}{|c|}{ Not Produced }} & $\kappa 5-\mathrm{H} 4$ & \multirow{4}{*}{\multicolumn{3}{|c|}{ Not Produced }} \\
\hline к5-H5 & & & & $\kappa 5-\mathrm{H} 5$ & & & \\
\hline к5-H6 & & & & к5-H6 & & & \\
\hline к5-H7 & 1.30 & 34.41 & 4.49 & к5-H7 & & & \\
\hline к6-H1 & 0.94 & 33.10 & 3.29 & к6-H1 & 0.57 & 27.22 & 1.52 \\
\hline к6-Н2 & 0.79 & 36.64 & 2.93 & к6-Н2 & \multicolumn{3}{|c|}{ Not Produced } \\
\hline к6-Н3 & 0.41 & 47.42 & 2.12 & к6-Н3 & 0.31 & 42.43 & 1.31 \\
\hline к6-Н4 & 0.81 & 36.58 & 2.64 & к6-Н4 & 1.80 & 21.44 & 3.86 \\
\hline к6-Н5 & 1.26 & 46.77 & 5.85 & к6-Н5 & 0.84 & 83.03 & 6.97 \\
\hline к6-Н6 & \multicolumn{3}{|c|}{ Not Produced } & к6-Н6 & 1.78 & 34.99 & 6.15 \\
\hline к6-Н7 & 0.98 & 49.74 & 4.85 & к6-Н7 & 0.60 & 50.44 & 2.98 \\
\hline
\end{tabular}

80 Figure 1. BLI measurements (KD, ka and kd) of Pertuzumab and Trastuzumab Vк1-6 and VH1-7

81 permutation binding to immobilized SpA biosensor. "Not Produced" denotes that there was

82 insufficient antibody production for the variant despite numerous large-scale transfections. All

83 readings were obtained from at least three antibody concentrations. The readings were the average of

84 independent triplicates. 


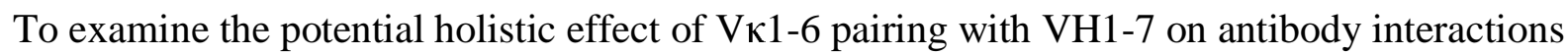
with SpA, recombinant Pertuzumab and Trastuzumab IgG1 variants of the various pairings were studied. It should be noted that $\mathrm{SpA}$ is known to bind to the $\mathrm{CH} 2$ and $\mathrm{CH} 3$ of the heavy chain 88 constant $(\mathrm{CH})$.

From Figure 1, the Pertuzumab and Trastuzumab IgG1 variants showed measurements bound 90 to SpA with the equilibrium dissociation constant (KD) at $0.41-1.90 \times 10^{-9} \mathrm{M}$ and $0.25-2.30 \times 10^{-9}$ 91 M, respectively.

For both Pertuzumab and Trastuzumab variants binding to SpA, VH3 was noticed to have a slightly lower, albeit insignificant KD difference at the average of $\sim 0.57 \times 10^{-9} \mathrm{M}$ and $\sim 0.53 \times 10^{-9}$

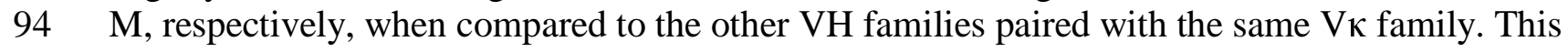
95 phenomenon is attributed to the higher ka and lower kd for the VH3 variant.

96

\subsection{Bio-Layer Interferometry (BLI) measurement of recombinant IgG1 variants to Protein G (SpG)}




\begin{tabular}{|c|c|c|c|c|c|c|c|}
\hline \multicolumn{4}{|c|}{ Pertuzumab variants binding Protein $G$} & \multicolumn{4}{|c|}{ Trastuzumab variants binding Protein G } \\
\hline $\begin{array}{l}\text { Variable } \\
\text { Pairings }\end{array}$ & $\begin{array}{c}\text { KD } \\
\left(\mathrm{M}, \mathbf{1 0}^{-9}\right)\end{array}$ & $\begin{array}{c}\text { ka } \\
\left(1 / \mathrm{Ms}^{2}, 10^{4}\right) \\
\end{array}$ & $\begin{array}{c}\text { kd } \\
\left(1 / \mathrm{s}, 10^{-4}\right) \\
\end{array}$ & \begin{tabular}{|l|} 
Variable \\
Pairings \\
\end{tabular} & $\begin{array}{c}\text { KD } \\
\left(\mathrm{M}, 10^{-9}\right) \\
\end{array}$ & $\begin{array}{c}\text { ka } \\
\left(1 / \mathrm{Ms}, 10^{4}\right) \\
\end{array}$ & $\begin{array}{c}\text { kd } \\
\left(1 / \mathrm{s}, 10^{-4}\right) \\
\end{array}$ \\
\hline к1-H1 & 0.28 & 33.22 & 0.92 & К1-H1 & \multirow{4}{*}{\multicolumn{3}{|c|}{ Not Produced }} \\
\hline$\kappa 1-\mathrm{H} 2$ & 0.31 & 32.59 & 1.02 & $\kappa 1-\mathrm{H} 2$ & & & \\
\hline к1-H3 & 0.87 & 30.74 & 2.22 & к1-H3 & & & \\
\hline к1-H4 & 0.30 & 35.54 & 1.04 & к1-H4 & & & \\
\hline к1-H5 & \multirow{2}{*}{\multicolumn{3}{|c|}{ Not Produced }} & к1-H5 & 0.29 & 32.31 & 0.91 \\
\hline к1-H6 & & & & к1-H6 & \multicolumn{3}{|c|}{ Not Produced } \\
\hline к1-H7 & 0.38 & 29.75 & 1.12 & к1-H7 & 0.39 & 30.19 & 1.16 \\
\hline$\kappa 2-\mathrm{H1}$ & 0.33 & 29.12 & 0.96 & $\kappa 2-\mathrm{H} 1$ & 0.39 & 25.84 & 1.00 \\
\hline К2-H2 & 0.36 & 29.18 & 1.05 & $\kappa 2-\mathrm{H} 2$ & 0.69 & 22.85 & 1.57 \\
\hline к2-H3 & 0.38 & 31.21 & 1.16 & $\kappa 2-\mathrm{H} 3$ & 0.29 & 34.26 & 0.98 \\
\hline К2-H4 & 0.25 & 34.56 & 0.83 & к2-H4 & 0.28 & 43.48 & 1.15 \\
\hline к2-H5 & 0.30 & 28.66 & 0.86 & $\kappa 2-\mathrm{H} 5$ & 0.27 & 37.63 & 0.97 \\
\hline$\kappa 2-\mathrm{H} 6$ & 0.32 & 30.00 & 0.95 & $\kappa 2-\mathrm{H} 6$ & 0.33 & 25.29 & 0.84 \\
\hline к2-H7 & 0.36 & 30.31 & 1.06 & к2-H7 & 0.23 & 33.30 & 0.77 \\
\hline$\kappa 3-\mathrm{H1}$ & 0.27 & 35.41 & 0.90 & $\kappa 3-\mathrm{H} 1$ & 0.31 & 30.26 & 0.92 \\
\hline к3-Н2 & 0.32 & 31.47 & 0.98 & $\kappa 3-\mathrm{H} 2$ & 0.48 & 32.91 & 1.55 \\
\hline к3-H3 & 0.30 & 31.52 & 0.94 & $\kappa 3-\mathrm{H3}$ & 0.24 & 31.94 & 0.78 \\
\hline$\kappa 3-\mathrm{H} 4$ & 0.24 & 35.67 & 0.86 & к3-H4 & 0.36 & 26.85 & 0.97 \\
\hline к3-H5 & 0.23 & 30.77 & 0.72 & к3-H5 & 0.23 & 35.48 & 0.81 \\
\hline к3-Н6 & 0.32 & 30.40 & 0.95 & к3-H6 & 0.44 & 32.45 & 1.42 \\
\hline к3-H7 & 0.27 & 29.36 & 0.78 & к3-H7 & 0.29 & 29.15 & 0.86 \\
\hline К4-H1 & 0.25 & 30.68 & 0.76 & К4-H1 & 0.36 & 25.16 & 0.89 \\
\hline к4-H2 & 0.25 & 32.17 & 0.78 & К4-H2 & \multicolumn{3}{|c|}{ Not Produced } \\
\hline к4-H3 & 0.25 & 30.90 & 0.75 & к4-H3 & 0.23 & 33.18 & 0.75 \\
\hline к4-H4 & 0.25 & 34.25 & 0.79 & к4-H4 & 0.25 & 35.90 & 0.89 \\
\hline к4-H5 & 0.32 & 26.48 & 0.83 & к4-H5 & 0.22 & 34.78 & 0.76 \\
\hline к4-H6 & 0.27 & 27.33 & 0.75 & К4-H6 & 0.38 & 23.19 & 0.87 \\
\hline к4-H7 & 0.28 & 28.25 & 0.81 & к4-H7 & 0.23 & 37.89 & 0.82 \\
\hline к5-Н1 & \multirow{2}{*}{\multicolumn{3}{|c|}{ Not Produced }} & к5-H1 & \multirow{2}{*}{\multicolumn{3}{|c|}{ Not Produced }} \\
\hline$\kappa 5-\mathrm{H} 2$ & & & & $\kappa 5-\mathrm{H} 2$ & & & \\
\hline к5-Н3 & 0.34 & 28.58 & 0.93 & $\kappa 5-\mathrm{H} 3$ & 0.32 & 26.71 & 0.84 \\
\hline к5-H4 & \multirow{3}{*}{\multicolumn{3}{|c|}{ Not Produced }} & к5-H4 & \multirow{4}{*}{\multicolumn{3}{|c|}{ Not Produced }} \\
\hline к5-H5 & & & & к5-H5 & & & \\
\hline к5-H6 & & & & к5-H6 & & & \\
\hline к5-Н7 & 0.32 & 31.62 & 1.01 & к5-H7 & & & \\
\hline к6-H1 & 0.29 & 30.14 & 0.87 & к6-H1 & 0.32 & 28.24 & 0.89 \\
\hline к6-Н2 & 0.31 & 31.57 & 0.93 & к6-Н2 & \multicolumn{3}{|c|}{ Not Produced } \\
\hline к6-Н3 & 0.28 & 36.72 & 1.00 & к6-H3 & 0.27 & 30.80 & 0.86 \\
\hline к6-H4 & 0.27 & 37.20 & 0.95 & к6-Н4 & 0.36 & 26.91 & 0.97 \\
\hline к6-H5 & 0.26 & 33.74 & 0.81 & к6-H5 & 0.22 & 41.89 & 0.90 \\
\hline к6-Н6 & & Not Produce & & к6-Н6 & 1.78 & 34.99 & 0.51 \\
\hline к6-Н7 & 0.28 & 33.32 & 0.89 & к6- & 0.30 & 31.67 & 0.93 \\
\hline
\end{tabular}

100 Figure 2. BLI measurements (KD, ka and kd) of Pertuzumab and Trastuzumab Vk1-6 and VH1-7

101 permutation binding to immobilized SpG biosensor. "Not Produced" denotes that there was

102 insufficient antibody production for the variants despite numerous large-scale transfections. All

103 readings were obtained from at least three antibody concentrations. The readings were the average of

104 independent triplicates. 
105 Testing the 63 recombinant Pertuzumab and Trastuzumab IgG1 variants with SpG which binds

106 to $\mathrm{CH} 2$ and $\mathrm{CH} 3$ region, we found high consistency of the interactions between the two Pertuzumab

107 and Trastuzumab IgG1 variants. Apart from showing similar KDs to the SpA, albeit with narrower

108 KD ranges of $0.23-0.87 \times 10^{-9} \mathrm{M}$ and $0.23-1.78 \times 10^{-9} \mathrm{M}$, respectively. There is a trend of

109 Pertuzumab variants binding SpG better than the Trastuzumab counterparts. This slight difference,

110 while unlikely significant, hints of CDR effects given that the variants differed only at a few residues

111 in the CDRs.

112

$113 \quad 3.3$ Bio-Layer Interferometry (BLI) measurement of recombinant IgG1 variants binding to 114 Protein L (PpL) 


\begin{tabular}{|c|c|c|c|c|c|c|c|}
\hline \multicolumn{4}{|c|}{ Pertuzumab variants binding Protein $\mathbf{L}$} & \multicolumn{4}{|c|}{ Trastuzumab variants binding Protein $\mathrm{L}$} \\
\hline $\begin{array}{l}\text { Variable } \\
\text { Pairings } \\
\end{array}$ & $\begin{array}{c}\text { KD } \\
\left(\mathbf{M}, 10^{-9}\right) \\
\end{array}$ & $\begin{array}{c}\text { ka } \\
\left(1 / \mathrm{Ms}, 10^{4}\right) \\
\end{array}$ & $\begin{array}{c}\text { kd } \\
\left(1 / \mathrm{s}, 10^{-4}\right) \\
\end{array}$ & $\begin{array}{l}\text { Variable } \\
\text { Pairings } \\
\end{array}$ & $\begin{array}{c}\text { KD } \\
\left(\mathbf{M}, \mathbf{1 0}^{-9}\right) \\
\end{array}$ & $\begin{array}{c}\text { ka } \\
\left(1 / M_{s}, 10^{4}\right)\end{array}$ & $\begin{array}{c}\mathbf{k d} \\
\left(1 / \mathrm{s}, 10^{-4}\right) \\
\end{array}$ \\
\hline к1-H1 & 0.76 & 15.40 & 1.15 & к1-H1 & \multirow{4}{*}{\multicolumn{3}{|c|}{ Not Produced }} \\
\hline к1-H2 & 0.68 & 13.90 & 0.93 & к1-H2 & & & \\
\hline к1-H3 & 0.53 & 18.09 & 0.84 & к1-H3 & & & \\
\hline к1-H4 & 0.57 & 15.23 & $\mathbf{0 . 8 3}$ & к1-H4 & & & \\
\hline к1-H5 & \multirow{2}{*}{\multicolumn{3}{|c|}{ Not Produced }} & к1-H5 & 0.11 & 15.71 & 0.17 \\
\hline к1-H6 & & & & к1-H6 & & Not Produces & \\
\hline к1-H7 & 0.68 & 16.05 & 1.08 & к1-H7 & 0.14 & 11.02 & 0.16 \\
\hline$\kappa 2-H I^{*}$ & 148.67 & 6.36 & 90.8 & $\kappa 2-\mathrm{H} 1$ & 124.41 & 0.84 & 9.49 \\
\hline$\kappa 2-H 2+$ & 15.77 & 1.68 & 2.03 & $\kappa 2-H 2+$ & 78.63 & 2.29 & 7.71 \\
\hline$\kappa 2-H 3+$ & 19.91 & 0.57 & 0.84 & $\kappa 2-\mathrm{H3}$ & \multirow{3}{*}{\multicolumn{3}{|c|}{ Poor Response }} \\
\hline к2-H4 & 14.4 & 0.36 & 0.3 & к2-H4 & & & \\
\hline$\kappa 2-\mathrm{H} 5$ & 0.93 & 8.72 & 0.81 & $\kappa 2-\mathrm{H5}$ & & & \\
\hline к2-H6 & 0.72 & 8.19 & 0.59 & $\kappa 2-H 6+$ & 190.4 & 0.24 & 3.53 \\
\hline$\kappa 2-H 7 *$ & 46.4 & 2.19 & 9.66 & $\kappa 2-H 7+$ & 9.79 & 1.51 & 0.78 \\
\hline к3-H1 & 38.03 & 91.86 & 86.08 & к3-H1 & 17.77 & 11.68 & 20.54 \\
\hline$\kappa 3-\mathrm{H} 2$ & 25.42 & 52.09 & 127.73 & к3-H2 & 3.67 & 7.63 & 2.58 \\
\hline к3-Н3 & 29.02 & 48.16 & 132.1 & к3-Н3 & 4.34 & 51.2 & 21.33 \\
\hline$\kappa 3-\mathrm{H} 4$ & 5.55 & 53.95 & 6.99 & к3-H4 & 5.5 & 29.5 & 15.52 \\
\hline$\kappa 3-\mathrm{H5}$ & 16.85 & 72.65 & 70.21 & к3-H5 & 4.54 & 49.16 & 22.25 \\
\hline к3-Н6 & 23.21 & 50.68 & 85 & к3-H6 & 9.04 & 15.37 & 13.53 \\
\hline к3-Н7 & 17.66 & 59.87 & 74.33 & к3-Н7 & 5.08 & 46.18 & 23.36 \\
\hline к4-H1 & 74.56 & 18.23 & 123 & к4-Н1 & 14.18 & 9.15 & 12.78 \\
\hline$\kappa 4-\mathrm{H} 2$ & 37.05 & 24.79 & 87.04 & К4-H2 & & Not Produces & \\
\hline к4-H3 & 13.09 & 22.76 & 19.45 & к4-H3 & 9.54 & 17.19 & 16.06 \\
\hline$\kappa 4-H 4$ & 13.66 & 26.24 & 20.37 & к4-H4 & 11.57 & 16.95 & 19.57 \\
\hline$\kappa 4-H 5$ & 54.38 & 12 & 64.34 & к4-H5 & 7.22 & 20.05 & 14.4 \\
\hline к4-H6 & 23.49 & 31.68 & 47.04 & к4-H6 & 13.03 & 14.32 & 18.55 \\
\hline к4-H7 & 34.95 & 20.99 & 65.46 & к4-Н7 & 10.31 & 20.34 & 19.79 \\
\hline к5-Н1 & \multirow{2}{*}{\multicolumn{3}{|c|}{ Not Produced }} & к5-H1 & \multirow{2}{*}{\multicolumn{3}{|c|}{ Not Produced }} \\
\hline$\kappa 5-\mathrm{H} 2$ & & & & к5-H2 & & & \\
\hline$\kappa 5-\mathrm{H} 3$ & 13.58 & 10.69 & 13.93 & $\kappa 5-\mathrm{H3}$ & 1.75 & 10.8 & 1.85 \\
\hline к5-Н4 & \multirow{3}{*}{\multicolumn{3}{|c|}{ Not Produced }} & к5-H4 & \multirow{4}{*}{\multicolumn{3}{|c|}{ Not Produced }} \\
\hline к5-Н5 & & & & к5-H5 & & & \\
\hline к5-Н6 & & & & к5-Н6 & & & \\
\hline к5-Н7 & 13.88 & 18.87 & 23.5 & к5-Н7 & & & \\
\hline к6-Н1 & \multirow{3}{*}{\multicolumn{3}{|c|}{ Poor Response }} & $\kappa 6-H 1+$ & 14.93 & 5.14 & 7.53 \\
\hline к6-Н2 & & & & $\kappa 6-\mathrm{H} 2$ & \multicolumn{3}{|c|}{ Not Produced } \\
\hline к6-Н3 & & & & $\kappa 6-H 3 *$ & 29.62 & 6.07 & 10.81 \\
\hline$\kappa 6-H 4 *$ & 43.46 & 3.81 & 10.43 & $\kappa 6-H 4 *$ & 74.9 & 1.65 & 8.96 \\
\hline$\kappa 6-H 5+$ & 15.79 & 1.77 & 2.8 & $\kappa 6-H 5 *$ & 14.84 & 16.49 & 11.17 \\
\hline к6-Н6 & \multicolumn{3}{|c|}{ Not Produced } & $\kappa \sigma-H \sigma^{*}$ & 82.16 & 1.28 & 8.36 \\
\hline к6-Н7 & 40.69 & 0.31 & 0.8 & к6-Н7 & 60.37 & 1.77 & 9.83 \\
\hline
\end{tabular}

116 Figure 3. BLI measurements (KD, ka and kd) of Pertuzumab and Trastuzumab Vк1-6 and VH1-7

117 permutation binding to immobilized SpG biosensor. "Not Produced" denotes that there was

118 insufficient antibody production for the variants despite numerous large-scale transfections. "Poor

119 response" indicates that the particular IgG1 pairing was unable to give response rates within the

120 detection limit across all concentrations. * denotes readings that were derived from two IgG1

This is a provisional file, not the final typeset article 
concentrations. + denotes represent readings generated derived from only one IgG1 concentration. All other readings were obtained from at least three concentrations. The readings were the average of independent triplicates.

From the total 63 permutations IgG1 variants consisting of 34 Pertuzumab and 29 Trastuzumab permutations of the grafted Vк1-6 and VH1-7 on PpL, our systematic and holistic

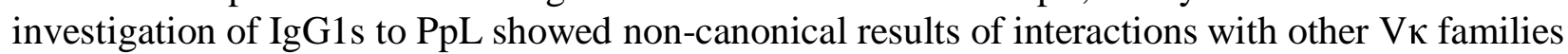
and a contributory role of VH-FWR and complementarity-determining regions (CDRs) to the interaction.

As a control for expected superantigen interactions, the Pertuzumab IgG1s of $\mathrm{V} \kappa 1,3$ and 4 interacted with PpL with $\mathrm{V} \kappa 1$ showing the lowest $\mathrm{KD}$ range $\left(0.53-0.76 \times 10^{-9} \mathrm{M}\right)$ followed by $\mathrm{V} \kappa 3$ $\left(5.55-38.03 \times 10^{-9} \mathrm{M}\right)$ and $\mathrm{V} \kappa 4\left(13.09-74.56 \times 10^{-9} \mathrm{M}\right)$. The $\mathrm{V} \kappa 1$ findings were consistent with previous literature (Åkerström and Björck, 1989;Rodrigo et al., 2015;Su et al., 2017). The lower equilibrium dissociation constants (KDs) of the $\mathrm{V} \kappa 3$ and 4 were due to the lower dissociation rates $(\mathrm{kd})$ despite the higher association rates $(\mathrm{ka})$ than $\mathrm{V} \kappa 1$. This trend was also observed for the

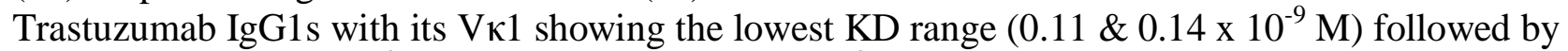
$\mathrm{V \kappa} 3\left(3.67-17.77 \times 10^{-9} \mathrm{M}\right)$ and $4\left(7.22-14.18 \times 10^{-9} \mathrm{M}\right)$. It should be noted that Trastuzumab IgG1s showed lower and a narrower KD range than the Pertuzumab Vк-VH equivalents suggesting effects from the CDRs which were what differed between the two sets of IgG1s.

Interestingly, certain Pertuzumab VHs paired with $\mathrm{V} \kappa 2,5$ and 6 exhibited interactions with

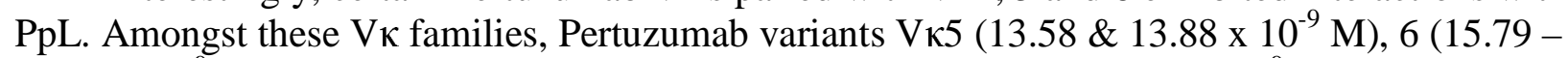
$43.46 \times 10^{-9} \mathrm{M}$ ) and certain $\mathrm{V \kappa} 2$ permutations (VH2-4 and 7, 14.4-46.4 x $10^{-9} \mathrm{M}$ ) had KDs

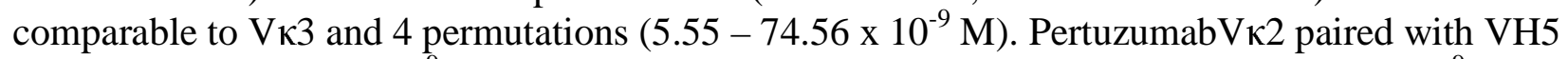
and 6 (0.93 and $0.72 \times 10^{-9} \mathrm{M}$, respectively) had KDs comparable to $\mathrm{V \kappa} 1\left(0.53-0.76 \times 10^{-9} \mathrm{M}\right)$ while $\mathrm{V \kappa} 2$ paired with VH1 had the highest KD (poorest binding) of $148.67 \times 10^{-9} \mathrm{M}$. There were also nonbinding IgG1s of the Pertuzumab Vк6 permutation with VH1-3 (Poor Response) despite measurable responses when paired with $\mathrm{VH} 4,5$ and 7.

Interesting, the Pertuzumab trends were largely repeated in the Trastuzumab IgG1s where KDs of $\mathrm{V} \kappa 5\left(1.75 \times 10^{-9} \mathrm{M}\right)$ and $6\left(14.84-82.16 \times 10^{-9} \mathrm{M}\right)$ and $\mathrm{V} \kappa 2$ paired with $\mathrm{VH} 2 \& 7(78.63 \& 9.79$ $\times 10^{-9} \mathrm{M}$, respectively) had KD values comparable to $\mathrm{V \kappa} 3$ and $4\left(3.67-14.18 \times 10^{-9} \mathrm{M}\right)$.

Trastuzumab Vк2 paired with VH1 \& 6 had the highest KD (poorest interaction) at $124.41 \& 190.4 \mathrm{x}$ $10^{-9} \mathrm{M}$, respectively. The non-binders were Trastuzumab V 2 paired with VH3 - 5 (Poor Response) rather than in Vк6 family observed for Pertuzumab. These differences demonstrated a role of the CDRs and a significant contributory role of $\mathrm{VH}$ in $\mathrm{PpL}$ engagement.

\section{Discussion}

We set out to investigate the interactions of superantigens Protein A, G and L systematically and holistically with the various regions of IgG1 antibodies. By using CDRs of Pertuzumab and Trastuzumab grafted onto Vк1-6 and VH1-7 FWRs and pairing them within the two antibody models, measurements to the antibody superantigens showed no major differences for SpA between Pertuzumab and Trastuzumab IgG1 variants (Figure 1). This was expected given that SpA bound IgG1s predominantly at the $\mathrm{CH} 2-\mathrm{CH} 3$ regions (Deisenhofer, 1981) with some contributions from the VH3 framework (Su et al., 2021) that is also observed here to a lesser extent where the Vк chains paired with VH3 showed a slightly lower KD measurement compared to the rest of the variants. Yet, 
164

165

166

this difference is notably less pronounced compared to our previous work on IgEs (Su et al., 2021) with the same Vks-VH where the VH3-CDR2 S58 residue had a more significant role in SpA binding for IgEs.

\section{With respect to $\mathrm{SpG}$ interaction, no notable differences in KDs (Figure 2) were observed} among the $63 \mathrm{IgG1}$ variants. As was with SpA, which shared an overlapping binding site on the $\mathrm{CH} 2-\mathrm{CH} 3$ region of IgGs (Kato et al., 1995), there was in fact a narrower range that we attributed to the lack of interference from the V-regions present for SpA. While SpG was previously reported (Choe et al., 2016) to bind to IgG1 better than SpA, this trend was more pronounced in our study.

Measurements of PpL interactions to Pertuzumab and Trastuzumab variants expectedly showed that VHs paired with Vк1, 3 and 4 to have KDs as per previously reported (Nilson et al., 1992;Su et al., 2017). Surprisingly, we found non-canonical interaction of $\mathrm{PpL}$ with $\mathrm{V} \kappa 2$ that were previously determined to not bind PpL (Nilson et al., 1992) while there is no report of $\mathrm{V} \kappa 5 \& 6$ at the time of writing. In our own work involving light chain productions alone, we also affirmed that these secreted Vк2, 5 and 6 light chain dimers did not interact with PpL on the same BLI experiments

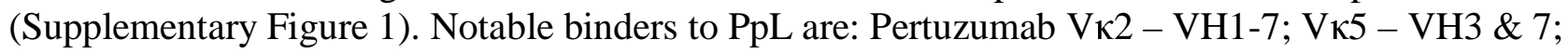

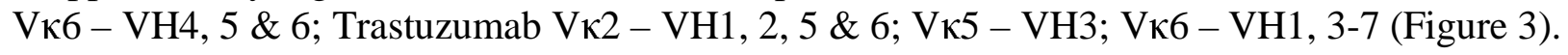

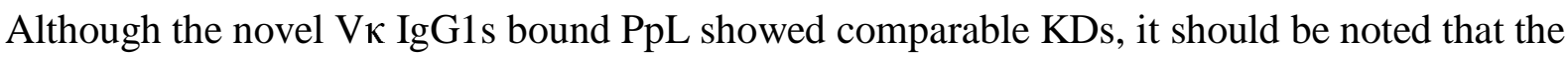
KDs were calculated from one (+ in Figure 3) or two (* in Figure 3) antibody concentrations, generally from the highest concentrations (100 nM and below) of the Ig variant. The notable

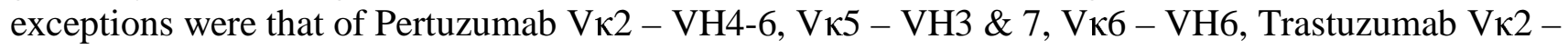
$\mathrm{VH} 1, \mathrm{~V} \kappa 5-\mathrm{VH} 3, \mathrm{~V} \kappa 6-\mathrm{VH} 7$ with KDs calculated from at least three concentrations. Interestingly,

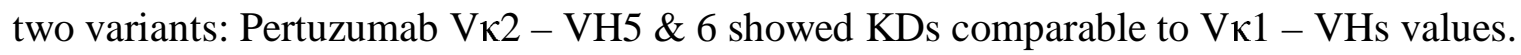

The unexpected IgG1 variants interacting with PpL suggested a combined VH-Vк induced binding site to PpL that may be similar to the non-canonical binding of IgEs to Nickel ( $\mathrm{Su}$ et al., 2021 ) in our previous work using the same V-regions. In fact, the IgG1s were validated with the expected interactions to $\mathrm{SpA}$ and $\mathrm{SpG}$ here, and also with the Fc $\gamma 2 \mathrm{~A}$ and Her2 in our previous work

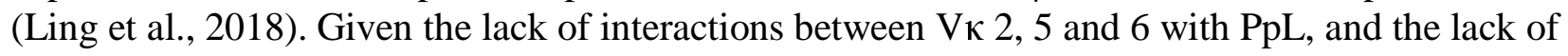
consistency between the Trastuzumab and Pertuzumab variants where for Pertuzumab, the non-

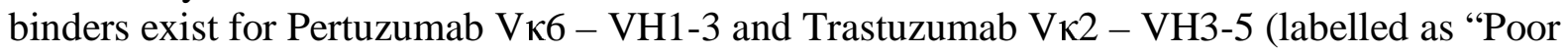
Response" pairs in Figure 3), the PpL interaction is certainly beyond V-region pairings alone.

With the differences between the Pertuzumab and Trastuzumab which share very similar Vregions, our findings further demonstrate the need for a design thinking (Ling et al., 2020a) approach involving holistic antibody investigations approach (Phua et al., 2019). Such an approach allowed detailed investigations for unexpected interactions between the antibodies with other proteins that can have notable immune effects, as was with our unexpected findings of IgAs binding to SpG (Ling et al., 2021). With relevance to the development of therapeutics where a personalized antibody approach may be beneficial to avoid unwanted side effects, such interactions may also be engineered in for purification purposes.

\section{Conflict of Interest}

The authors declare that the research was conducted in the absence of any commercial or financial relationships that could be construed as a potential conflict of interest.

This is a provisional file, not the final typeset article 


\section{Author Contributions}

208 Conceptualization, W.L.L. and S.K-E.G.

209 Methodology, W.L.L. and S.K-E.G.

210 Investigation, W.L.L. and S.K-E.G

211 Validation, J.Y.Y.

212 Writing - Original Draft, W.L.L. and S.K-E.G

213 Writing - Review \& Editing, W.L.L., Y.L.N. and S.K-E.G

214 Funding Acquisition, S.K-E.G.

215 Supervision, S.K-E.G., Y.L.N. and A.W.

\section{$217 \quad 7 \quad$ Funding}

This work was partially supported by the Joint Council Office, Agency for Science,

\section{Acknowledgments}

This is a short text to acknowledge the contributions of specific colleagues, institutions, or agencies that aided the efforts of the authors.

225

\section{$9 \quad$ References}

Åkerström, B., and Björck, L. (1989). Protein L: An Immunoglobulin Light Chain-binding Bacterial Protein: Characterization of binding and physicochemical properties *. Journal of Biological Chemistry 264, 19740-19746.

Chan, W.-T., Verma, Chandra s., Lane, David p., and Gan, Samuel k.-E. (2013). A comparison and optimization of methods and factors affecting the transformation of Escherichia coli. Bioscience Reports 33.

Choe, W., Durgannavar, T.A., and Chung, S.J. (2016). Fc-Binding Ligands of Immunoglobulin G: An Overview of High Affinity Proteins and Peptides. Materials (Basel, Switzerland) 9, 994.

Deacy, A.M., Gan, S.K.-E., and Derrick, J.P. (2021). Superantigen Recognition and Interactions: Functions, Mechanisms and Applications. Frontiers in Immunology 12. 
237

238

239

240

241

242

243

244

245

246

247

248

249

250

251

252

253

254

255

256

257

258

259

260

261

262

263

264

265

266

267

268

269

270

271

272

273

274

275

276

277

Deisenhofer, J. (1981). Crystallographic refinement and atomic models of a human Fc fragment and its complex with fragment B of protein A from Staphylococcus aureus at 2.9- and 2.8-.ANG. resolution. Biochemistry 20, 2361-2370.

Gan, S.K.P., S.; Yeo, J.Y. (2021). Sagacious Epitope Selection for Vaccines, and Both AntibodyBased Therapeutics and Diagnostics: Tips From Virology and Oncology. Preprints.

\section{Grov, A., Myklestad, B., and Oeding, P. (1964). IMMUNOCHEMICAL STUDIES ON ANTIGEN PREPARATIONS FROM STAPHYLOCOCCUS AUREUS. Acta Pathologica Microbiologica Scandinavica 61, 588-596.}

Haraldsson, Á., Kock-Jansen, M.J.H., Jaminon, M., V Eck-Arts, P.B.J.M., De Boo, T., Weemaes, C.M.R., and Bakkeren, J.a.J.M. (1991). Determination of Kappa and Lambda Light Chains in Serum Immunoglobulins G, A and M. Annals of Clinical Biochemistry 28, 461-466.

Janeway, C.A., Travers, P., Walport, M., and Capra, D.J. (2001). Immunobiology. Taylor \& Francis Group UK: Garland Science.

Kato, K., Lian, L.-Y., Barsukov, I.L., Derrick, J.P., Kim, H., Tanaka, R., Yoshino, A., Shiraishi, M., Shimada, I., Arata, Y., and Roberts, G.C.K. (1995). Model for the complex between protein G and an antibody Fc fragment in solution. Structure 3, 79-85.

Ling, W.-L., Lua, W.-H., and Gan, S.K.-E. (2020a). Sagacity in antibody humanization for therapeutics, diagnostics and research purposes: considerations of antibody elements and their roles. Antibody Therapeutics 3, 71-79.

Ling, W.-L., Lua, W.-H., Poh, J.-J., Yeo, J.Y., Lane, D.P., and Gan, S.K.-E. (2018). Effect of VHVL Families in Pertuzumab and Trastuzumab Recombinant Production, Her2 and Fc $\gamma$ IIA Binding. Frontiers in Immunology 9.

Ling, W.-L., Su, C.T.-T., Lua, W.-H., Poh, J.-J., Ng, Y.-L., Wipat, A., and Gan, S.K.-E. (2020b). Essentially Leading Antibody Production: An Investigation of Amino Acids, Myeloma, and Natural V-Region Signal Peptides in Producing Pertuzumab and Trastuzumab Variants. Frontiers in Immunology 11.

Ling, W.-L., Su, C.T.-T., Lua, W.-H., Yeo, J.Y., Poh, J.-J., Ng, Y.-L., Wipat, A., and Gan, S.K.-E. (2021). Engaging the 'A' Class Antibody: Variable-Heavy (VH) region influencing IgA1 \&amp;2 engagement of Fc $\alpha$ RI and superantigen proteins $\mathrm{G}, \mathrm{A}$, and L. bioRxiv, 2021.2009.2027.461897.

Lua, W.-H., Ling, W.-L., Yeo, J.Y., Poh, J.-J., Lane, D.P., and Gan, S.K.-E. (2018). The effects of Antibody Engineering $\mathrm{CH}$ and CL in Trastuzumab and Pertuzumab recombinant models: Impact on antibody production and antigen-binding. Scientific Reports 8, 718.

Lua, W.-H., Su, C.T.-T., Yeo, J.Y., Poh, J.-J., Ling, W.-L., Phua, S.-X., and Gan, S.K.-E. (2019a). Role of the IgE variable heavy chain in Fc\&\#x3b5;RI\&\#x3b1; and superantigen binding in allergy and immunotherapy. Journal of Allergy and Clinical Immunology 144, 514-523.e515.

Lua, W.-H., Su, C.T.-T., Yeo, J.Y., Poh, J.-J., Ling, W.-L., Phua, S.-X., and Gan, S.K.-E. (2019b). Role of the IgE variable heavy chain in FceRI $\alpha$ and superantigen binding in allergy and immunotherapy. Journal of Allergy and Clinical Immunology 144, 514-523.e515.

Nilson, B.H., Solomon, A., Björck, L., and Akerström, B. (1992). Protein L from Peptostreptococcus magnus binds to the kappa light chain variable domain. J Biol Chem 267, 2234-2239. 
Phua, S.-X., Chan, K.-F., Su, Chinh t.-T., Poh, J.-J., and Gan, Samuel k.-E. (2019). Perspective: The promises of a holistic view of proteins - impact on antibody engineering and drug discovery. Bioscience Reports 39.

Rodrigo, G., Gruvegård, M., and Van Alstine, J.M. (2015). Antibody Fragments and Their Purification by Protein L Affinity Chromatography. Antibodies 4, 259-277.

Samsudin, F., Yeo, J.Y., Gan, S.K.-E., and Bond, P.J. (2020). Not all therapeutic antibody isotypes are equal: the case of IgM versus IgG in Pertuzumab and Trastuzumab. Chemical Science 11, 2843-2854.

Sasso, E.H., Silverman, G.J., and Mannik, M. (1991). Human IgA and IgG F(ab')2 that bind to staphylococcal protein A belong to the VHIII subgroup. The Journal of Immunology 147, 1877-1883.

Sjöbring, U., Björck, L., and Kastern, W. (1991). Streptococcal protein G. Gene structure and protein binding properties. J Biol Chem 266, 399-405.

Spaulding, A.R., Salgado-Pabón, W., Kohler, P.L., Horswill, A.R., Leung, D.Y.M., and Schlievert, P.M. (2013). Staphylococcal and Streptococcal Superantigen Exotoxins. Clinical Microbiology Reviews 26, 422-447.

Su, C.T.-T., Ling, W.-L., Lua, W.-H., Poh, J.-J., and Gan, S.K.-E. (2017). The role of Antibody Vк Framework 3 region towards Antigen binding: Effects on recombinant production and Protein L binding. Scientific Reports 7, 3766.

Su, C.T.-T., Lua, W.-H., Ling, W.-L., and Gan, S.K.-E. (2018). Allosteric Effects between the Antibody Constant and Variable Regions: A Study of IgA Fc Mutations on Antigen Binding. Antibodies 7, 20.

Su, C.T.-T., Lua, W.-H., Poh, J.-J., Ling, W.-L., Yeo, J.Y., and Gan, S.K.-E. (2021). Molecular Insights of Nickel Binding to Therapeutic Antibodies as a Possible New Antibody Superantigen. Frontiers in Immunology 12.

\section{Data Availability Statement}

The datasets GENERATED/ANALYZED for this study is available upon request.

\section{Figure Legends}

Figure 1. BLI measurements (KD, ka and kd) of Pertuzumab and Trastuzumab Vk1-6 and VH1-7 permutation binding to immobilized SpA biosensor. "Not Produced" denotes that there was insufficient antibody production for the variant despite numerous large-scale transfections. All readings were obtained from at least three antibody concentrations. The readings were the average of independent triplicates.

Figure 2. BLI measurements (KD, ka and kd) of Pertuzumab and Trastuzumab Vк1-6 and VH1-7 permutation binding to immobilized SpG biosensor. "Not Produced" denotes that there was insufficient antibody production for the variants despite numerous large-scale transfections. All 
316 readings were obtained from at least three antibody concentrations. The readings were the average of 317 independent triplicates.

318 Figure 3. BLI measurements (KD, ka and kd) of Pertuzumab and Trastuzumab Vк1-6 and VH1-7

319 permutation binding to immobilized SpG biosensor. "Not Produced" denotes that there was

320 insufficient antibody production for the variants despite numerous large-scale transfections. "Poor 321 response" indicates that the particular IgG1 pairing was unable to give response rates within the 322 detection limit across all concentrations. * denotes readings that were derived from two IgG1 323 concentrations. + denotes represent readings generated derived from only one IgG1 concentration.

324 All other readings were obtained from at least three concentrations. The readings were the average of 325 independent triplicates. 